\title{
Preparedness activities and research needls in addressing emerging infectious animal and zoonotic diseases
}

\author{
S. Cardoen ${ }^{(1)}$, K. De Clercq ${ }^{(2)}$, L. Vanholme ${ }^{(3)}$, P. De Winter ${ }^{(3)}$, E. Thiry ${ }^{(4,5)}$ \\ \& X. Van Huffel ${ }^{(1)}$ \\ (1) Staff Direction for Risk Assessment, Directorate-General of Control Policy, Federal Agency for the Safety \\ of the Food Chain, Boulevard du Jardin Botanique 55, 1000 Brussels, Belgium \\ (2) Unit of Vesicular and Exotic Diseases, CODA-CERVA, Groeselenberg 99, 1180 Brussels, Belgium \\ (3) Department for Animal Health and Safety of Animal Products, Directorate-General of Control Policy, \\ Federal Agency for the Safety of the Food Chain, Boulevard du Jardin Botanique 55, 1000 Brussels, Belgium \\ (4) Veterinary Virology and Animal Viral Diseases, Department of Infectious and Parasitic Diseases, Faculty of \\ Veterinary Medicine, University of Liege, Quartier Vallée 2, Avenue de Cureghem 10, B43bis, 4000 Liège, Belgium \\ (5) Scientific Committee of the Belgian Federal Agency for the Safety of the Food Chain, Boulevard du Jardin \\ Botanique 55, 1000 Brussels, Belgium \\ *Corresponding author: sabine.cardoen@afsca.be
}

\section{Summary}

Emerging infectious animal and zoonotic diseases can inflict significant losses on animal production and public health, and threaten the safety and security of the food system. Threat analysis (forecasting), which monitors the measurable risk indicators of disease emergence, should be in place before the emergence of any threat. Animal and public health authorities develop and regularly re-evaluate disease preparedness, response and recovery plans, based on the 'One Health' principle. These plans should include surveillance, biosecurity measures, communication channels and training for personnel. Scenarios for outbreaks of natural emerging infectious disease or bioterrorist events should be prepared and practised. National and international legislation should be regularly updated to provide a robust legal basis to manage outbreaks. Reference laboratories should have reliable and validated diagnostic tools for rapid, high-throughput testing. Strict biosafety, biocontainment and biosecurity control measures must be implemented in laboratories in order to prevent the accidental or malicious release of pathogens. The pharmaceutical industry should be incentivised to develop vaccines and/or antiviral drugs against disease outbreaks. Conventions between public authorities and the pharmaceutical industry should guarantee adequate stockpiling of the pharmaceuticals needed to control large-scale outbreaks.

In the early phase of disease emergence (early warning), veterinarians and stakeholders play an important role in early detection at the farm level. Upon notification, veterinary authorities must take rapid response measures to limit disease spread.

National and international short- and medium-term strategic research agendas should be developed, based on a comprehensive gap analysis and horizon scan. This planning will help to guide funding agencies and non-governmental organisations in their quest to support relevant research.

\section{Keywords}

Accidental emergence - Deliberate introduction - Emerging animal disease - Natural emergence - Preparedness - Research - Zoonotic disease.

\section{Introduction}

Emerging infectious animal and zoonotic diseases may result in significant losses to the animal production and public health sectors and can threaten the safety and security of the food system. Governments and decision-makers are obliged to prepare for potential disease outbreaks, whether they result from natural, accidental (from laboratories), or 
deliberate (bioterrorism) release. Adequate preparation for, early detection of and response to emerging diseases are ongoing concerns.

Whether animal disease outbreaks are caused by natural events or an accidental or deliberate release, the mechanisms for disease detection, notification and control are similar. However, accidental and deliberate releases can differ from classic natural introductions. A deliberate release can carry special risks because pathogens may have been engineered for increased virulence or intentionally released into dense, vulnerable populations to maximise harm. In the case of a natural outbreak, depending on the virulence of the organism, the index case is usually unique and spread may occur gradually. This allows time for Veterinary Services to be alerted and take appropriate control measures. In the case of a deliberate (malicious) release, there is a high probability that the pathogen will be disseminated in several locations simultaneously. Veterinary and public health authorities must implement surveillance systems so that they can recognise patterns of non-specific syndromes that could indicate the early manifestation of a biological warfare attack (1). An increased response capacity and higher level of preparedness are therefore necessary in order to contain and control the spread of multiple simultaneous outbreaks from such a release (2).

Preparedness is the responsibility of all professionals involved in maintaining animal health and public health, and of those involved in ensuring the safety of the food chain. 'Preparedness' is a broad term, encompassing research and the development of policies that ultimately result in tools, technology, education and training to support increased awareness, surveillance, traceability, early detection, response and recovery (3). Preparedness measures should be developed with a 'One Health' approach that involves both Veterinary and Health Services, laboratories and clinics, environmental experts, livestock farmers and other animal keepers, and last, but certainly not least, risk assessors and risk managers.

In this article, the authors discuss emerging infectious animal and zoonotic disease preparedness in relation to the chronology of events that should occur before, during and after a disease emergence and/or outbreak (Fig. 1). Before disease emergence (anticipation), forecasting, risk assessment and risk management activities should be performed by risk assessors and risk managers. In the early phase of disease emergence, veterinarians, farmers and other stakeholders play an important role in early detection and notification. Prompt disease notification is crucial in controlling a disease outbreak and minimising its economic consequences. After a disease emerges, a robust response is needed in the form of control measures. Typically, this response is supported by the proper authorities, risk managers and epidemiologists, among others.

Funding agencies, non-governmental organisations (NGOs) and the veterinary research community also have an important role to play in preparing for infectious animal and zoonotic disease emergencies. Short- and mediumterm research priorities should be established within a robust process to identify the research requirements of a broad community of veterinary experts and stakeholders. This process should include the prioritisation of recommendations and needs, and a discussion of the appropriate policies required to support new technologies, tools and countermeasures. In short, a strategic research agenda should be developed, with clear priorities, milestones and funding.

Tools and methods that can be used for this purpose include: the Delphi expert solicitation (4), gap analysis and prioritisation (5), horizon scanning of the forces that drive animal disease emergence, scenario-building and foresight studies (6).

\section{Preparing for emerging infectious animal and zoonotic disease outbreaks}

Active and passive animal disease surveillance focus on the (early) detection of diseases already present in the territory

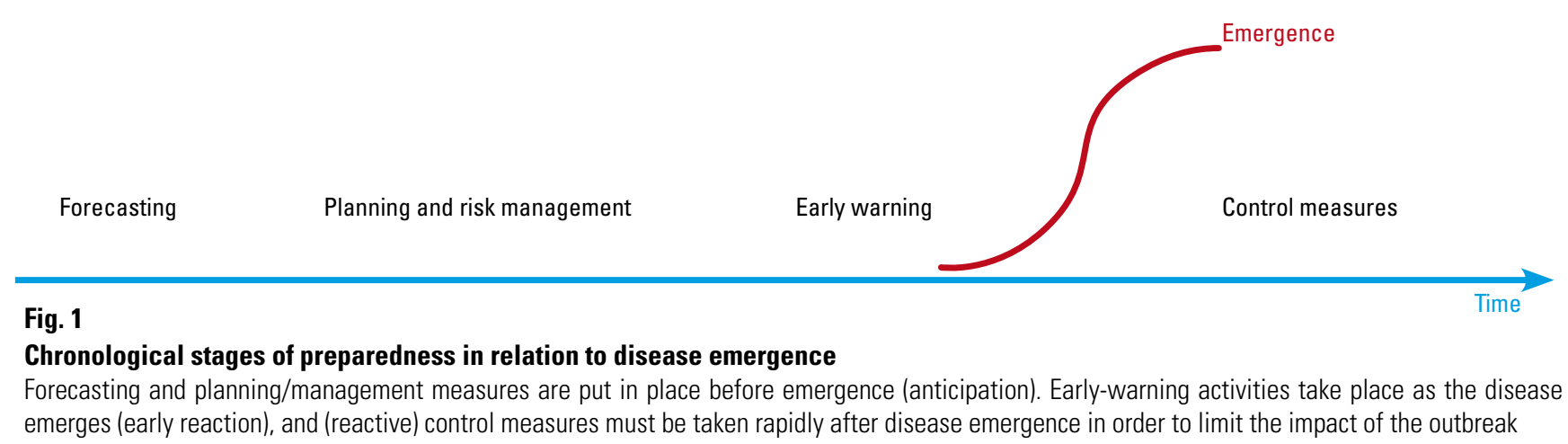


or region concerned. These methods are based on clinical signs and diagnostic testing, systems that play a vital role in early detection but form only one component of an effective disease detection programme. Furthermore, they are unable to predict the next emerging infectious animal disease outbreak.

When preparing for emerging infectious animal and zoonotic disease outbreaks, forecasting the risk of disease incursions can be considered as the first anticipatory action. Further actions are described in the 'Planning and risk management' section, below.

\section{Predicting the risk of disease incursions}

Predicting disease incursions and outbreaks is a major challenge for veterinary and public health authorities. A better understanding of risk factors and their role in the likelihood that a new emerging animal or zoonotic disease will develop and threaten populations is needed. Understanding these risk factors is critical in accurately predicting a major disease outbreak or new disease emergence. Several studies have evaluated risk factors in disease emergence and these studies provide a comprehensive list of common drivers that lead to emerging diseases and outbreaks (i.e. 7, 8, 9, 10).

In recent advice (11), the Scientific Committee of the Belgian Federal Agency for the Safety of the Food Chain noted that certain risk indicators of disease emergence are measurable and it is possible to monitor their evolution over time. The Committee recommended that veterinary authorities further develop methods to monitor risk indicators for disease emergence. Such indicators should be monitored closely for trends and threshold crossings, and provide automated alerts when an increased risk of animal disease introduction or spread occurs. Ideally, these systems will alert the veterinary and public health communities before a disease is introduced or an outbreak occurs or - at the very least - in the early stages of disease emergence.

As an example, the international status of animal diseases can be used as an early indicator. Periodic monitoring of this indicator is possible via such Web interfaces as the World Organisation for Animal Health (OIE) alerts and the World Animal Health Information Database (WAHID), the European Animal Disease Notification System (ADNS) and the Programme for Monitoring Emerging Diseases (ProMED). When combined with a structured follow-up of imports and the trade of animals and animal products, via the European Trade Control and Expert System (TRACES), these databases provide valuable information to enable authorities to anticipate the risk of disease emergence in a specific country. However, in the case of a bioterrorist threat, special attention should be drawn to the illegal trade in animals and their products, Customs and border control, ports, etc.
Threat analysis based on monitoring measurable risk indicators is a valuable first step in increasing the awareness of a potential disease outbreak.

\section{Planning and risk management}

Planning and risk management are early-phase components when preparing for a disease outbreak or emergence. This stage encompasses:

- planning for disease prevention and control

- ensuring laboratory readiness (i.e. training staff and validating diagnostic tests and biosafety)

- developing and testing vaccines

- coordinating of medical, veterinary, and ecological health systems and components

- ensuring that appropriate legislation is in place to support animal health authorities during a disease incursion.

\section{Prevention and control planning}

Public authorities should develop strategic plans to combat emerging animal and zoonotic diseases. These plans should have clear objectives with regard to detection, surveillance and response; infrastructure; diagnostic tool development, validation and deployment; training; and prevention and control. These plans should also be founded on the One Health principle and should be promptly implemented as soon as a disease incursion is suspected. In addition, robust communication plans should be developed and put into practice when a suspected outbreak is confirmed. Good communication with producers and the public will help to minimise disease spread, enhance biosecurity and prevent panic.

Preparations should make intensive use of multidisciplinary teams and collaboration, and result in strong partnerships between medical and veterinary professionals, epidemiologists, microbiologists, etc. All programmes aimed at controlling and eradicating emerging infectious diseases (EIDs) should be regularly re-evaluated.

A strategic disease control plan should also take into account, forecast, and plan for the necessary human and financial resources to support all aspects of its implementation.

Preventive, predictive and reactive contingency plans, including simulation exercises, are necessary to enable the early implementation of control measures. Scenarios for a naturally occurring EID outbreak as well as for outbreaks caused by an intentional introduction should be prepared and practised.

Livestock farmers should be educated on the need to practise strict biosecurity measures on a daily basis. The routine 
implementation of these measures will ensure that, during times of an outbreak, these practices are already in place.

The identification and registration of animals and animal products is crucial for monitoring movements and tracing disease outbreaks. Comprehensive and interconnected databases that include information such as animal identification, certification, movements, laboratory data, pathogen characteristics, epidemiological outbreak information, etc., should be established and maintained. The information in these databases, although confidential, should be easily accessible to animal health authorities in the event of an outbreak.

The surveillance of domestic and wildlife animal species must be adequately organised in order to ensure early detection and, when appropriate, to demonstrate the absence of a disease.

Notifications to the OIE and World Health Organization (WHO), and the exchange of information among countries are essential in the event of a transboundary and/or zoonotic disease outbreak. The Global Framework for the Progressive Control of Transboundary Animal Diseases (GF-TADs) was launched by the OIE and Food and Agriculture Organization of the United Nations (FAO) in 2004 (12). In the event of a zoonotic disease, WHO is linked with GF-TADs through the Global Early Warning and Response System (GLEWS). GLEWS' objective is to improve the early detection of health threats, and information on the events of significance to animal, human or ecosystem health is exchanged daily. WHO and FAO host and jointly manage a global network of national food safety authorities, the International Food Safety Authorities Network (INFOSAN), which alerts National Focal Points when there is regional or global concern over a food safety event.

International coordination and cooperation are indicated when a disease has the potential for rapid, general spread across national boundaries and large regions. Coordination between public and animal health services or the 'One Health principle' should be applied, especially in the case of a zoonotic emerging disease.

\section{Legislation and guidelines}

There are general and specific global agreements, guidelines and resolutions, requirements and recommendations for preparing for and responding to a disease event. In addition, the European Union (EU) member States and many other countries each have their own policies, legislation and regulations related to disease preparedness, response and recovery. Legislation to support disease response should be kept up to date and should legally support risk managers as they take the necessary action to protect animal and public health.
On the international level, resolutions and recommendations have been agreed upon among the OIE Member Countries. These countries are legally bound to report outbreaks of OIE-listed diseases and emerging diseases quickly and with transparency through the online World Animal Health Information System (WAHIS). Once validated, this information is rapidly disseminated through the WAHID system. Timely sharing of disease information enables a rapid and effective international response and may prevent the future spread of diseases. Health measures are described in the OIE Terrestrial Animal Health Code and Aquatic Animal Health Code $(13,14)$ after being formally adopted by Member Countries at the annual General Assembly.

\section{Laboratory preparedness}

Early detection is the single most important aspect of minimising production losses as well as reducing the spread and cost of a disease outbreak (15). Syndromic and laboratory surveillance play a critical role in the early detection and characterisation of an outbreak. Except for truly novel diseases, diagnostic tests are described for most exotic and emerging diseases in the OIE Manual of Diagnostic Tests and Vaccines for Terrestrial Animals (Terrestrial Manual) and the Manual of Diagnostic Tests for Aquatic Animals (Aquatic Manual) $(16,17)$. Laboratories should carry out these tests based on a list of priorities, which should be regularly reviewed, depending on the risk assessments performed for their country.

If these tests are not carried out within the country, then the national laboratory responsible should have a firm agreement with an OIE or FAO Reference Laboratory, guaranteeing diagnostic capability in the event of an outbreak in the country concerned. Full validation $(16,17)$ of these tests can be difficult as representative positive field samples are hard to obtain in countries where the disease is not endemic or occurs sporadically. This can make it difficult to get an accurate measurement of test sensitivity within the desired population. In many cases, when positive samples are not available, the laboratory can gain confidence in its performance of the test by requesting reference samples from the network of international reference laboratories. The laboratory can then obtain the specificity of the test, using samples from its own negative population.

It is crucial to understand the test performance and percentage of false positives and false negatives before a disease introduction. Decisions on animal health status and movement are often made using these test results, so it is vital for the decision-maker to understand the performance of the test in the animal population that is being tested. For antibody detection tests, it is important to understand the capability of the assay Differentiating Infected from Vaccinated Animals (DIVA), especially if the animal population is vaccinated, in which case, samples 
from a non-vaccinated population should be obtained. If a DIVA test is available to differentiate the infected from the vaccinated animals (18), a determination of specificity using samples from a vaccinated population (19) should be part of the validation process and included in the validation dossier.

The availability of rapid or pen-side tests, such as lateral flow devices (20) for antibody or antigen detection, means that these tests can be performed in the field or laboratory to triage samples. However, it is critical that these tests are validated and fit for purpose. If the test is to be used in a field setting, validation and training should be carried out in that setting. Training in the performance and interpretation of these assays requires a pre-established decision tree to guide the response to a positive or negative test result.

Once a new EID is detected in a country, the number of samples to be analysed can increase exponentially. As part of laboratory preparedness, advance agreements should be made to allow for the movement of samples from the outbreak area to other laboratories for testing. This will help to ensure increased capacity in the event of a largescale outbreak. The establishment of a network of regional laboratories within the country is also very useful. The latter requires the organisation of training and proficiency tests to ensure a well-prepared network (21). However, the need for a regional network of laboratories is not always considered a priority during 'peace time'.

One of the responsibilities of laboratories for exotic and emerging diseases is to follow the evolution and spread of these diseases on the international level. In this respect, the spread of lumpy skin disease from Africa, which began in 2012 via the Middle East to Turkey in 2013 (22), and continued on to Cyprus in 2014 and Greece in 2015, should have been a very clear signal for other European laboratories to prepare their diagnostic capability for this disease. However, the evolution of these diseases is not always predictable, as illustrated by an unexpected epidemic of West Nile virus, which began in New York in 1999 (23); the detection of foot and mouth disease virus (FMDV) in 2001 in the United Kingdom (24); the still-unexplained appearance of bluetongue virus (BTV), serotype 8, in north-western Europe in 2006 (25); and the introduction of African swine fever virus into Georgia in 2007 (26). Although the diagnostic techniques needed for these diseases could be implemented quite quickly, as the basic technologies required, such as enzymelinked immunosorbent assay, virus isolation or reversetranscription polymerase chain reaction, are standard practices at most laboratories, it is far better to be prepared and to have a working capability, as well as reagents for these diseases, prior to their introduction.

\section{Laboratory biosafety and biosecurity}

Many pathogens that are handled in veterinary laboratories are dangerous to both human and animal health. Effective, risk-based biosafety measures are essential to protect the safety of personnel who may be exposed to such agents. The OIE Terrestrial Manual (Chapter 1.1.4.) (16) provides biosafety guidelines for veterinary laboratories and animal facilities. For pathogens such as FMDV, special guidelines have been developed by the European Commission (EC). Reference to these guidelines is made in the EC Directive on foot and mouth disease (FMD), making them obligatory in the EU (27). Effective biocontainment and biosecurity should prevent the release of pathogens from the laboratory and further prevent their malicious use by terrorists or as bio-weapons. Four biocontainment levels have been defined by the OIE, based on the risk to animal health and public health.

Ideally, all public, private and university laboratories should install and maintain the required biocontainment level to handle specific pathogens. However, not all countries have the resources to build and maintain a P3 or P4 laboratory. Moreover, many of these pathogens are endemic in those countries.

\section{Vaccines and antivirals: collaboration with industry}

Close collaboration between national and/or international authorities and pharmaceutical companies is required when a newly developed vaccine is needed to control an EID. However, the development and production of a vaccine is a reactive process if the emerging pathogen was previously unknown. In that case, a quick procedure for vaccine development, licensing and marketing authorisation is needed. A perfect example of this type of response was provided by the introduction of Schmallenberg virus into Europe. Conventional inactivated vaccines against the virus were quickly released onto the market. This was facilitated by a rapid industrial development process and an expedited procedure for obtaining a temporary marketing authorisation from the European Medicines Agency (EMA). The same approach was followed for BTV serotype 8 vaccines although, in this case, the virus was already known and the industry was able to transfer its technology from previous BT serotypes to prepare a new vaccine that addressed BTV serotype 8 (28).

Indeed, in the case of known pathogens, and based on an analysis of the risk of emergence, the availability of vaccines can be anticipated through the following approaches:

i) Antigen and vaccine banks can be created, as the EU did for FMDV vaccines, in collaboration with pharmaceutical companies (29). 
ii) 'Mock-up' vaccines can be created. This procedure, accepted by EMA for human pandemic influenza vaccines, involves the development of a vaccine that is identical in composition and in the manufacturing process to the 'eventual' pandemic vaccine (30). It contains a viral strain that can quickly be adapted by the insertion of pandemic strain antigen sequences. There is no known example in veterinary medicine thus far.

iii) The vaccine strain can be adapted by incorporating strains that are antigenically similar to the circulating viruses. The only example of this in veterinary medicine thus far is the recommendation of the OIE Expert Surveillance Panel on Equine Influenza Vaccine Composition that strains be selected for equine influenza in accordance with the current epidemiological situation (31).

Antivirals are still under development in veterinary medicine. In the case of FMD and classical swine fever, the use of antiviral drugs has been discussed as an alternative to vaccination or a supplementary method to be used in previously virus-free countries or zones. The use of such antiviral treatments in a vaccinated zone could protect against viral dissemination and bridge the time gap between vaccination and the development of protective immunity. This approach is now theoretically envisaged as an alternative or complement to emergency vaccination $(32,33)$.

\section{Strong and coordinated health systems (One Health)}

When a zoonotic disease occurs, whether naturally or through the deliberate or accidental introduction of a disease agent, coordination of the animal health and public health response is essential, at both the national and international levels. In the case of diseases affecting wildlife, coordination with those authorities responsible for wildlife surveillance will be necessary. When there is suspicion of deliberate release, collaboration with law enforcement agencies is an important part of the response. To reduce biothreats, a focus on strengthening, enhancing and developing cross-links between existing health systems is of primary importance. Coordination between existing structures must be planned and prepared well in advance of a natural or intentional outbreak.

\section{Early warning}

\section{Surveillance and early detection}

A major aspect of preparedness for emerging animal and zoonotic diseases is the development and implementation of robust surveillance systems that allow the early detection of disease. The most effective and sustainable way to protect against threats from deliberate and accidental releases of animal pathogens is to strengthen existing systems for surveillance and early on-farm detection. We need surveillance networks that include a key role for the farmer/producer and veterinary practitioner. The farmer and veterinarian are often the first to observe a sick animal and thus are key components in any effective surveillance system. In addition, the veterinary practitioner has an obligation to notify the proper animal health authority of a suspect notifiable disease. The relationship between the farmer and veterinary practitioner is based on trust and cooperation.

\section{Disease reporting and notification}

General or specific agreements, requirements, guidelines and/or recommendations for reporting a disease event exist on the global level. In addition, EU member States and many other countries also have their own legislation and regulations that specify lists of notifiable diseases and/ or methods of reporting a suspected animal disease event, whether emerging or zoonotic.

In the EU, Council Directive 82/894/EEC and Commission Implementing Decision 2012/737/EU set out the requirements for the notification of animal diseases within the Union and the development and use of the Animal Disease Notification System for direct notifications $(34,35)$.

Member Countries of the OIE have committed themselves to providing all necessary information to achieve control of emerging diseases and minimise their spread. The transparent notification of diseases and epidemiological information is outlined in the Terrestrial Animal Health Code and the Aquatic Animal Health Code (13, 14). Information should be transmitted to the OIE by OIE Member Countries through direct notification, with follow-up reports and sixmonthly or annual reports.

Under the International Health Regulations (2005) (36), binding 194 countries across the globe, all cases of the following four diseases must be automatically notified to WHO: smallpox, poliomyelitis due to wild-type poliovirus, severe acute respiratory syndrome (SARS) and cases of human influenza caused by a new subtype.

\section{Control measures}

Many countries have a defined list of control measures and guidelines that must be applied in the event of an EID outbreak. A few of these measures/guidelines are:

- mandatory notification of suspected cases or outbreaks

- official surveillance of suspected/infected holdings, with periodic veterinary checks and regular inspections

- carrying-out of epidemiological surveys

- the imposing of disease control and biosecurity measures, depending on the animal health and epidemiological situation 
- emergency slaughter of animals or the implementation of a test-and-slaughter strategy

- the imposition of a stamping-out policy

- specific measures for processing the carcasses of dead or euthanased animals and animal by-products

- the disposal or recycling of animal carcasses and waste

- the regionalisation or delimitation of restricted zones, in which special conditions are applied to the movement of or trade in certain animals and animal products

- the installation of temporary controls in a protection zone of $3 \mathrm{~km}$ around an outbreak, and a surveillance zone of $10 \mathrm{~km}$

- monitoring the movements of animals

- a restriction or total ban on the movement of animals, people and vehicles into or out of a holding under surveillance

- the establishment of requirements and/or conditions for allowing animals and/or animal products on the market, for trade and import

- implementing strict biosecurity standards

- ensuring the appropriate cleansing and disinfection of vehicles, equipment, and other items moving on and off affected premises

- imposing preventive control measures on in-contact herds, slaughterhouses, border inspection posts, transportation vehicles, and for the transport and distribution of animal manure from susceptible species

- the establishment of sanitary measures for feed, forage, hay and straw

- performing clinical exams and serological surveys to determine disease status within a holding, region or country

- developing legal provisions for effective, proportionate and dissuasive penalties applicable to infringements of mandatory measures

- implementing an emergency protective or suppressive vaccination policy

- establishing requirements and conditions for restocking affected premises (e.g. the use of sentinel animals).

The EU has specific legislation for a number of animal diseases, depending on their social and economic impact. This legislation covers notification obligations, diagnostic methods, and measures to be applied when the disease is suspected or confirmed, as well as - where applicable regionalisation measures.

\section{Research needs for emerging infectious animal diseases}

Research on the prevention and control of endemic diseases is often carried out at the national level. Research into EIDs, animal and zoonotic, sometimes takes place at the global level.

There are comprehensive needs for research on emerging and zoonotic diseases, and international cooperation and coordination of research programmes are highly indicated. In the past, networks have been set up across Europe among research fund providers, including the Coordination of European Research on Emerging and Major Infectious Diseases of Livestock (EMIDA ERA-Net) and the Coordination of European Research on Animal Health and Welfare (ANIHWA ERA-Net). Both of these databases have since been incorporated into a single resource (www.scarcwg-ahw.org).

At the international level, there is the Global Strategic Alliances for the Coordination of Research on the Major Infectious Diseases of Animals and Zoonoses network (STAR-IDAZ) (www.star-idaz.net). STAR-IDAZ has been conducting foresight studies as part of an objective to improve the prioritisation and coordination of research into the major infectious diseases of animals, including zoonoses. It is hoped that enhanced coordination and prioritisation will speed up the delivery of improved countermeasures. The goal of these foresight studies was to identify scientific and technological needs, research capacity and support structures to leverage and enhance research programmes so that they could more effectively deliver technologies and tools to prevent, control or mitigate animal health and zoonotic challenges to 2030 and beyond.

The STAR-IDAZ International Research Consortium includes organisations and NGOs that fund and perform research in Europe, Asia, Australia, the Americas, Africa and the Middle East. Other international organisations and veterinary pharmaceutical companies are also included. Together, they have set a total budget in the region of US $\$ 2.5$ billion to invest in animal health research over a fiveyear period from 2016-2021. Partners of the consortium have agreed to coordinate their research programmes to address agreed-upon needs, share their results, and together deliver new and improved animal health strategies for at least 30 priority diseases, infections and issues. This work focuses on developing candidate vaccines, diagnostics, therapeutics and other animal health products, procedures and/or key scientific information and tools to support risk analysis and disease control.

Priority topics for collaboration have been identified. They are categorised by discipline (immunology, vaccinology 
and diagnostics, epidemiology and foresight, animal health genomics) and disease (influenza, bovine tuberculosis, foot and mouth disease, brucellosis, African swine fever, rabies, respiratory diseases of pigs, vector-borne diseases, coronaviruses, parasitic diseases, mastitis and foodborne pathogens). Another important area is antimicrobial resistance and the development of alternatives to antimicrobial agents.

Identifying and prioritising research needs for animal diseases is an important step which has also been tackled by the EU Seventh Framework Programme's Disease Control Tools (DISCONTOOLS) project (5) for some 50 diseases. This project is still ongoing, with private funding. A gap analysis for each of the prioritised diseases is being further developed to identify research needs in the areas of diagnostics, vaccines and pharmaceuticals.

Current initiatives for international collaboration on research into EIDs and zoonotic diseases are being undertaken in the framework of the HORIZON 2020 European Research and Innovation programme (https://ec.europa.eu/programmes/ horizon2020).

On the national level, research programmes focused on EIDs and zoonotic diseases are often developed on the basis of specific short- and medium-term needs and take into consideration specific local situations and research capacity. In Belgium, the Risk-Based Increase of Diagnostic Capacities for Epizootic Diseases in Belgium (EPIDIACAP) project (www.coda-cerva.be/index.php?option=com_content $\&$ view=article\&id $=560$ \&lang $=\mathrm{fr}$ ) is aimed at defining the research needs of epizootic disease diagnostics. The main objectives of this project are to identify diagnostic gaps in order to optimise the mass detection of epizootic diseases which pose the greatest threat of introduction and to expand this diagnostic capacity through a sound selection of tests for development or optimisation.

According to Christopher (37), veterinary research in the next decade must strengthen the scientific impact of its core mission in animal health while firmly reinforcing its societal and global relevance. Key research challenges include waterand food-borne pathogens and drug residues, zoonotic pathogens and infectious diseases, and evidence-based companion animal medicine and its potential applications to human health. Meeting these challenges will require crossdisciplinary global collaboration, significant investment in national research, and online publishing tools to facilitate networking and open scientific exchange.

\section{Conclusion}

How to predict the unpredictable, the next emerging infectious animal disease, zoonosis or emerging biological threat? Veterinary and medical services, authorities and laboratories should prepare themselves for emergent disease outbreaks. The best way to be prepared is to study and evaluate the threats (forecasting), to enhance awareness and training for professionals in the animal sector (through syndromic surveillance and early warning), and to keep veterinary and medical diagnostic and response capacity at a high level. This will require proactive and constructive collaboration and information exchange between all involved stakeholders: farmers, professionals working in the field, regional and national laboratories, veterinary and medical authorities, pharmaceutical companies and the research community.

Preparedness against an unknown EID poses a true challenge for risk managers and veterinary authorities. New tools are now available, including refined laboratory techniques for diagnostics and medicinal products, as well as biostatistics and epidemiological computer models for determining spread. The next crucial step should be focusing on evaluating, monitoring, alerting and responding to the measurable drivers of disease emergence.

\title{
Préparation et besoins en recherche dans le domaine des maladies animales infectieuses émergentes et des zoonoses
}

\author{
S. Cardoen, K. De Clercq, L. Vanholme, P. De Winter, E. Thiry \\ \& X. Van Huffel
}

\author{
Résumé \\ Les maladies animales infectieuses et les zoonoses émergentes ont un coût élevé \\ pour la santé animale et la santé publique, en plus d'entraîner d'importantes \\ pertes de production dans les élevages et de menacer la sécurité des systèmes
}


de production alimentaire. Une analyse des menaces (anticipation), grâce au suivi d'indicateurs mesurables du risque d'émergence des maladies animales, devrait être en place avant que ces menaces n'émergent. Les autorités en charge de la santé animale et de la santé publique développent et réévaluent régulièrement des plans de préparation, de réponse et de récupération vis-à-vis de maladies, sur la base du principe "Une seule santé ". Ces plans doivent inclure des mesures de surveillance et de biosécurité, en plus de se doter de moyens de communication et de formation du personnel. II convient d'élaborer et de mettre en pratique des scénarios d'émergence de maladies infectieuses, que celle-ci soit d'origine naturelle ou d'origine bioterroriste. Les législations nationales et internationales en la matière doivent être actualisées régulièrement afin de fournir un fondement juridique solide à la gestion des émergences. Les laboratoires de référence doivent disposer d'outils diagnostiques fiables et validés permettant la réalisation de tests rapides et à haut débit. Des mesures strictes de contrôle de la biosécurité, du bioconfinement et de la biosûreté doivent être appliquées dans les laboratoires pour prévenir toute libération accidentelle ou malintentionnée d'agents pathogènes. L'industrie pharmaceutique doit être incitée au développement de vaccins et d'antiviraux pour maîtriser les maladies émergentes. Les conventions entre les autorités publiques et l'industrie pharmaceutique doivent permettre de garantir la constitution de stocks suffisants de produits pharmaceutiques pour maîtriser les émergences de grande ampleur.

Lors des premières phases d'émergence d'un foyer (alerte précoce), les vétérinaires et autres acteurs de terrain jouent un rôle important dans la détection précoce au niveau des élevages. Dès la notification d'un foyer, les autorités vétérinaires doivent réagir rapidement afin d'en limiter la propagation.

Il convient de développer des programmes nationaux et internationaux de recherche stratégique à court et moyen terme, basés sur un examen exhaustif des lacunes et sur une analyse prospective complète. Cette planification contribuera à fournir aux agences de financement et aux organisations non gouvernementales des orientations leur permettant de déterminer quel soutien apporter à la recherche.

\title{
Mots-clés
}

Émergence accidentelle - Émergence naturelle - Introduction délibérée - Maladie animale émergente - Préparation - Recherche - Zoonose.

\section{Preparación y necesidades de la investigación sobre las enfermedades animales infecciosas emergentes y las zoonosis}

\author{
S. Cardoen, K. De Clercq, L. Vanholme, P. De Winter, E. Thiry \\ \& X. Van Huffel
}

\section{Resumen}

Las enfermedades animales infecciosas y las zoonosis emergentes pueden causar pérdidas cuantiosas en los ámbitos de la producción animal y la salud pública, además de amenazar la higiene y la seguridad de los sistemas alimentarios. El análisis (pronóstico) de amenazas, que consiste en seguir de cerca indicadores cuantificables del riesgo de aparición de enfermedades animales, es algo que debería estar implantado antes de que surja toda amenaza. Las autoridades sanitarias y zoosanitarias definen y periódicamente reevalúan planes de preparación, respuesta y recuperación frente a enfermedades, basándose para ello en el principio de "Una sola salud». Estos planes deben incluir labores de vigilancia y medidas de seguridad biológica, además de prever cauces de comunicación y actividades de formación del personal. También hay que elaborar y aplicar 
planes para hipotéticos brotes infecciosos, ya sean de origen natural u obra de bioterroristas. Asimismo, a fin de contar con sólidas bases jurídicas para combatir la aparición de enfermedades, es preciso actualizar periódicamente la legislación nacional e internacional. Los laboratorios de referencia deben contar con herramientas de diagnóstico fiables y validadas que permitan efectuar pruebas rápidas y de alto rendimiento. Es preciso implantar en los laboratorios estrictas medidas de control de la protección, la contención y la seguridad biológicas para evitar toda liberación accidental o malintencionada de patógenos. Hay que incentivar asimismo a la industria farmacéutica para que desarrolle vacunas y fármacos antivirales contra las enfermedades emergentes. Por otra parte, las autoridades públicas deben suscribir con el sector farmacéutico convenios que garanticen la constitución de reservas suficientes de los productos farmacéuticos requeridos para hacer frente a la aparición de brotes de grandes dimensiones.

En las primeras fases de la aparición de un foco (alerta rápida), los veterinarios y otros interlocutores cumplen una importante función para detectar con prontitud la patología dentro de las explotaciones. Al recibir notificación, las autoridades veterinarias deben reaccionar con rapidez para poner coto a la propagación de la enfermedad.

Por último, a partir de un análisis exhaustivo de las carencias existentes y de un estudio prospectivo completo, es preciso elaborar planes nacionales e internacionales de investigación estratégica a corto y medio plazo. Tal planificación ayudará a orientar a los organismos de financiación y las organizaciones no gubernamentales (ONG) en su labor de apoyo a las investigaciones de interés.

\section{Palabras clave}

Aparición accidental - Aparición natural - Enfermedad animal emergente - Enfermedad zoonótica - Introducción deliberada - Investigación - Preparación.

\section{References}

1. Pinto V.N. (2013). - Bioterrorism: health sector alertness. J. Nat. Sci. Biol. Med., 4 (1), 24-28. doi:10.4103/09769668.107256.

2. Lillibridge S.R., Bell A.J. \& Roman R.S. (1999). - Centers for Disease Control and Prevention bioterrorism preparedness and response. Am. J. Infect. Control, 27 (6), 463-464. doi:10.1016/ S0196-6553(99)70020-9.

3. Levings R.L. (2012). - Emerging and exotic zoonotic disease preparedness and response in the United States - coordination of the animal health component. Zoonoses Public Hlth, 59 (2), 80-94. doi:10.1111/j.1863-2378.2012.01495.x.

4. Wentholt M., Cardoen S., Imberechts H., Van Huffel X., Ooms B. \& Frewer L. (2012). - Defining European preparedness and research needs regarding emerging infectious animal diseases: results from a Delphi expert consultation. Prev. Vet. Med., 103 (2-3), 81-92. doi:10.1016/j. prevetmed.2011.09.02.

5. DISCONTOOLS (2017). - About DISCONTOOLS. Available at: www.discontools.eu/AboutDiscontools (accessed on 6 August 2017).
6. Bagni M., Zilli R., Messori S. \& Mariano V. (2015). Fore-Med report 2014. Animal health foresight for the Mediterranean. Italian Ministry of Health, Rome. Available at: www.salute.gov.it/imgs/C_17_EventiStampa_260_interviste Relatori_itemInterviste_0_fileAllegatoIntervista.pdf (accessed on 6 August 2017).

7. Nederlandse Voedsel-en Warenautoriteit (Food and Consumer Product Safety Authority) (NVWA) (2005). - Pan-European identification of emerging risks in the field of food production (PERIAPT). Final report. NVWA, Utrecht, the Netherlands. Available at: www.elika.net/datos/ redes_europeas_docs/Documento 1/1.Informe\%20final \%20Emerging\%20Risks\%20Identification\%20Booklet_ Periapt.pdf (accessed on 14 August 2017).

8. Nederlandse Voedsel-en Warenautoriteit (Food and Consumer Product Safety Authority) (NVWA) (2006). - Forming a global system for identifying food-related emerging risks (EMRISK). EFSA/SC/Tender/01/2004. Final report. NVWA, Utrecht, the Netherlands. doi:10.2903/j.efsa.2005.224r. 
9. European Food Safety Authority (EFSA) (2014). - Drivers of emerging risks and their interactions in the domain of biological risks to animal, plant and public health: a pilot study. EFSA Support. Public., 11 (4), 44 pp. doi:10.2903/ sp.efsa.2014.EN-588.

10. Scientific Committee of the Federal Agency for the Safety of the Food Chain (Belgium) (2013). - Advice 06-2013 on risk factors of the (potentially) (re)-emerging infectious animal diseases [in French]. Available at: www.favv-afsca.fgov.be/ comitescientifique/avis/2013/_documents/AVIS06-2013_FR_ DossierSciCom2006_48.pdf (accessed on 7 August 2017).

11. Scientific Committee of the Federal Agency for the Safety of the Food Chain (Belgium) (2016). - Advice 10-2016 (and appendix) on prospects for a monitoring of risk indicators (threat analysis) for alert setting of emergence of animal diseases [in French]. Available at: www.favv-afsca.fgov.be/ comitescientifique/avis/2016/_documents/Avis10-2016_ Monitoringemergence_000.pdf. Appendix available at: www. favv-afsca.fgov.be/comitescientifique/avis/2016/_documents/ Avis10-2016_Monitoringemergence_Appendix.pdf (accessed on 7 August 2017).

12. Food and Agriculture Organization of the United Nations (FAO), World Organisation for Animal Health (OIE) \& World Health Organization (WHO) (2008). - The FAO-OIE-WHO collaboration: sharing responsibilities and coordinating global activities to address health risks at the animal-humanecosystem interfaces. A tripartite concept note. FAO, Rome; OIE, Paris; WHO, Geneva. Available at: www.who.int/ influenza/resources/documents/tripartite_concept_note_ hanoi_042011_en.pdf (accessed on 7 August 2017).

13. World Organisation for Animal Health (OIE) (2017). Terrestrial Animal Health Code. OIE, Paris. Available at: www. oie.int/international-standard-setting/terrestrial-code/accessonline/ (accessed on 7 August 2017).

14. World Organisation for Animal Health (OIE) (2017). - Aquatic Animal Health Code. OIE, Paris. Available at: www.oie.int/ international-standard-setting/aquatic-code/access-online/ (accessed on 7 August 2017).

15. Welby S., van Schalk G., Veldhuis A., Brouwer-Middelesch H., Peroz C., Santman-Berends I.M., Fourichon C., Wever P. \& Van der Stede Y. (2016). - Effectiveness and cost efficiency of different surveillance components for proving freedom and early detection of disease: bluetongue serotype 8 in cattle as case study for Belgium, France and the Netherlands. Transbound. Emerg. Dis. doi:10.1111/tbed.12564.

16. World Organisation for Animal Health (OIE) (2017). - Chapter 1.1.6. Principles and methods of validation of diagnostic assays for infectious diseases. In Manual of Diagnostic Tests and Vaccines for Terrestrial Animals. OIE, Paris. Available at: www.oie.int/international-standard-setting/terrestrial-manual/ access-online/ (accessed on 30 August 2017).

17. World Organisation for Animal Health (OIE) (2017). - Manual of Diagnostic Tests for Aquatic Animals. OIE, Paris. Available at: www.oie.int/international-standard-setting/aquatic-manual/ access-online/ (accessed on 30 August 2017).
18. Vannier P., Capua I., Le Potier M.F., Mackay D.K.J., Muylkens B., Parida S., Paton D.J. \& Thiry E. (2007). Marker vaccines and the impact of their use on diagnosis and prophylactic measures. In Animal vaccination - Part 2: scientific, economic, regulatory and socio-ethical aspects (P.-P. Pastoret, M. Lombard \& A.A. Schudel, eds). Rev. Sci. Tech. Off. Int. Epiz., 26 (2), 351-372.

19. Brocchi E., Bergmann I.E., Dekker A., Paton D.J., Sammin D.J., Greiner M., Grazioli S., De Simone F., Yadin H., Haas B., Bulut N., Malirat V., Neitzert E., Goris N., Parida S., Sorensen K. \& De Clercq K. (2006). - Comparative evaluation of six ELISAs for the detection of antibodies to the non-structural proteins of foot-and-mouth disease virus. Vaccine, 24 (47-48), 6966-6979. doi:10.1016/j.vaccine. 2006.04.050.

20. Hanon J.B., Vandenberge V., Deruelle M., De Leeuw I., De Clercq K., Van Borm S., Koenen F. \& Van der Stede Y. (2016). - Inter-laboratory evaluation of the performance parameters of a lateral flow test device for the detection of bluetongue-specific antibodies. J. Virol. Methods, 228, 140-150. doi:10.1016/j.jviromet.2015.12.001.

21. Zientara S., Sailleau C., Bréard E., Viarouge C., Doceul V. $\&$ Vitour D. (2015). - Benefits of PCR and decentralization of diagnosis in regional laboratories in the management of bluetongue in France. Vet. Ital., 51 (4), 393-399. doi:10.12834/ VetIt.512.3148.2.

22. Tuppurainen E. \& Oura C. (2014). - Lumpy skin disease: an African cattle disease getting closer to the EU. Vet. Rec., 175 (12), 300-301. doi:10.1136/vr.g5808.

23. Nash D., Mostashari F., Fine A., Miller J., O'Leary D., Murray K., Huang A., Rosenberg A., Greenberg A., Sherman M., Wong S. \& Layton M. (2001). - The outbreak of West Nile virus infection in the New York City area in 1999. N. Engl. J. Med., 344 (24), 1807-1814. doi:10.1056/ NEJM200106143442401.

24. Anderson I. (2002). - Foot and mouth disease 2001: lessons to be learned inquiry report, HC888. Stationery Office, London. Available at: http://webarchive.nationalarchives. gov.uk/20100807034701/http:/archive.cabinetoffice.gov. $\mathrm{uk} / \mathrm{fmd} / \mathrm{fmd}$ _report/report/index.htm (accessed on 30 June 2016).

25. Toussaint J.-F, Sailleau C., Mast J., Houdart P., Czaplicki G., Demeestere L., VandenBussche F., Van Dessel W., Goris N., Bréard E., Bounaadja L., Thiry E., Zientara S. \& De Clercq K. (2007). - Bluetongue in Belgium. Emerg. Infect. Dis., 13 (4), 614-616. doi:10.3201/eid1304.061136.

26. Rowlands R.J., Michaud V., Heath L., Hutchings G., Oura C., Vosloo W., Dwarka R., Onashvili T., Albina E. $\&$ Dixon L.K. (2008). - African swine fever virus isolate, Georgia. Emerg. Infect. Dis., 14 (12), 1870-1874. doi:10.3201/ eid1412.080591. 
27. European Commission for the Control of Foot-and-Mouth Disease (EuFMD) (2013). - Minimum biorisk management standards for laboratories working with foot-and-mouth disease virus. Version GS40/4.2bis, as adopted by the 40th General Session of the EuFMD Commission, 22-24 April 2013, Rome, Italy. EuFMD, Rome. Available at: www.fao. org/fileadmin/user_upload/eufmd/Lab_guidelines/FMD_ Minimumstandards_2013_Final_version.pdf (accessed on 1 July 2016).

28. Saegerman C., Hubaux M., Urbain B., Lengelé L. \& Berkvens D. (2007). - Regulatory issues surrounding the temporary authorisation of animal vaccination in emergency situations: the example of bluetongue in Europe. In Animal vaccination - Part 2: scientific, economic, regulatory and socio-ethical aspects (P.-P. Pastoret, M. Lombard \& A.A. Schudel, eds). Rev. Sci. Tech. Off. Int. Epiz., 26 (2), 395-413. doi:10.20506/rst.26.2.1747.

29. Lombard M. \& Füssel A.E. (2007). - Antigen and vaccine banks: technical requirements and the role of the European antigen bank in emergency foot and mouth disease vaccination. In Animal vaccination - Part 1: development, production and use of vaccines (P.-P. Pastoret, M. Lombard \& A.A. Schudel, eds). Rev. Sci. Tech. Off. Int. Epiz., 26 (1), 117-134.

30. Palache B. \& Krause R. (2009). - Progress with human H5N1 vaccines: a perspective from industry. Expert Rev. Vaccines, 8 (4), 391-400. doi:10.1586/erv.09.16.

31. World Organisation for Animal Health (OIE) (2016). - OIE Expert Surveillance Panel on Equine Influenza Vaccine Composition, OIE Headquarters, 22 March 2017: conclusions and recommendations. OIE, Paris. Available at: www.oie. int/en/our-scientific-expertise/specific-information-andrecommendations/equine-influenza/ (accessed on 25 April 2017).
32. Dal Pozzo F. \& Thiry E. (2014). - Antiviral chemotherapy in veterinary medicine: current applications and perspectives. Rev. Sci. Tech. Off. Int. Epiz., 33 (3), 791-801. doi:10.20506/ rst.33.3.2318.

33. Backer J.A., Vrancken R., Neyts J. \& Goris N. (2013). - The potential of antiviral agents to control classical swine fever: a modelling study. Antiviral Res., 99 (3), 245-250. doi:10.1016/j. antiviral.2013.06.013.

34. European Union (EU) (1982). - European Union Council Directive 82/894/EEC of 21 December 1982 on the notification of animal diseases within the Community. Off. J. Eur. Union, L378, of 31/12/1982, 58-62. Available at: http://data.europa. eu/eli/dir/1982/894/oj (accessed on 7 August 2017).

35. European Commission (EC) (2012). - 2012/737/EU: Commission Implementing Decision of 27 November 2012 amending Annexes I and II to Council Directive 82/894/EEC on the notification of animal diseases within the Community (notified under document C(2012) 8518). Text with EEA relevance. Off. J. Eur. Union, L329, of 29/11/2012, 19-22. Available at: http://data.europa.eu/eli/dec_impl/2012/737/oj (accessed on 7 August 2017).

36. World Health Organization (WHO) (2016). - International Health Regulations (2005): revised edition, 3rd Ed. WHO, Geneva, 84 pp. Available at: www.who.int/ihr/ publications/9789241580496/en/ (accessed on 7 August 2017).

37. Christopher M.M. (2015). - A new decade of veterinary research: societal relevance, global collaboration, and translational medicine. Front. Vet. Sci., 2, 1. doi:10.3389/ fvets.2015.00001. 